\title{
A Corte Internacional de Justiça e o Direito do Mar*
}

\author{
Vicente Marotta Rangel \\ Professor Titular de Direito Internacional Público na \\ Faculdade de Direito da Universidade de São Paulo.
}

E postulado básico do direito internacional o dever dos Estados de resolverem pacificamente as controvérsias de que participarem. Não se exigem processos específicos. A solução dos litígios pode ser alcançada através de processos políticos (negociação, bons ofícios, conciliação, consulta, resolução de órgãos políticos) ou de processos jurídicos (arbitragem e solução judiciária) . Da solução jurídica é a Corte Internacional de Justiça o principal órgão das Nações Unidas. E natural, pois, que a ela tenham solicitado os Estados solução para suas controvérsias, inclusive as referentes ao direito do mar, como veremos a seguir.

Constituída, ao término da segunda guerra mundial, como novo tribunal, não deixa a Corte de manter semelhanças substanciais com o órgão de solução judiciária da Sociedade das Nações. Também este dirimiu controvérsias sobre direito do mar. Tendem os litígios, porém, a aumentar de importância e número com o decorrer dos anos, conquanto nem sempre cresçam no mesmo grau e se aprimorem adequadamente os respectivos sistemas de soluções. Não cabe estranhar a freqüência de litígios a que esse direito se aplica, uma vez que três quartas partes do planeta formam a hidrosfera e avulta, progressivamente, a quantidade de navios que sigram o oceano, tanto quanto nele se acentuam, cada vez mais, in-

* Aula inaugural do ano letivo de 1976. 
teresses econômicos, políticos, estratégicos. Foi e continua sendo o mar o principal meio de comunicação entre os povos, pois que é através dele que cerca de oitenta por cento do intercâmbio de bens se processa. As estatísticas revelam haver duplicado o comércio internacional durante a década de 19601970, devido, em grande parte, ao transporte de petróleo, sendo oportuno lembrar que já para 1980 se prevê que somente a Europa Ocidental importará 680 bilhões de toneladas (métricas) de ouro negro conduzido por navios-cisternas.

Do relevo e alcance do direito do mar dizem os nomes dos navios que vão perpassando nos capítulos mais diversos do Direito Internacional: Santa Catarina, no da polêmica da liberdade dos mares; Alabama, no do estatuto da neutralidade; Montijo, no das relações entre normas internas e internacionais; Sapphire, no da representação estatal; Schooner Exchange, no da imunidade do Estado; Caroline, em matéria de legítima defesa... No rol da jurisprudência da antiga Corte Permanente de Justiça Internacional, nomes de navios também se fazem presentes. Basta lembrar o do Lotus que se invoca para as questões sobre competência criminal em alto mar e o do Wimbledon que se cita a respeito de tópicos sobre conflito de normas bem como sobre responsabilidade internacional dos Estados.

Embora sem a constância de outrora, nomes de navios também permeiam fastos do direito internacional mais recentes, posteriores à segunda guerra mundial. E o caso do Saumarez e Volage, citados a propósito do conflito entre a GrãBretanha e a Albânia sobre o trânsito no estreito de Corfu. A menção de nomes de navios atesta, por sinal, a presença de dois tradicionais usos do mar: o relativo ao transporte de pessoas e bens e o concernente à exploração dos recursos biológicos. Tendência moderna da jurisprudência é a de refletir a influência crescente de outros usos oceânicos, tais como o são a exploração dos recursos naturais da plataforma continental e dos fundos oceânicos, a produção de energia, a pes- 
quisa científica. À medid̉a que esses novos usos surgem e se intensificam, a incidência de navios tenderia, parece, a constituir-se menor. Em relação à pesca, as embarcações utilizadas, por outro lado, são numerosas e de dimensões reduzidas. Dir-se-ia que quase não mereceriam serem conhecidas pelo nome. . Dos diferentes usos do mar, cada vez mais variados, cada vez mais intensos, resulta, outrossim, o fenômeno alarmante de poluição oceânica, a qual tende, por sua vez, a ser fator de litígios, alguns dos quais se delineiam no plano internacional, como o que poderia surgir entre a Finlândia, de um lado, e países do Attântico sul, como o nosso, de outro lado, a propósito da carga delectéria transportada em maio do ano passado pelo Enskeri, o qual, em boa hora, retornou à sua base de partida.

Às portas da Corte Internacional de Justiça o tema da poluição teve ensejo, por sua vez, de ressoar, de modo aliás candente, a propósito de controvérsias sobre as experiências nucleares atmosféricas que Paris se propusera a promover sobre Mururoa e Fangataufa, no arquipélago de Tonamotu, Polinésia francesa. A 9 de maio de 1973, os governos da Austrália e da Nova Zelândia, submetendo à Corte pedido para que a governo gaulês suspendesse esses testes, requereu fossem eles julgados incompatíveis com normas de direito internacional. À pertinência dessa controvérsia com o direito do mar reside na alegação dos Estados autores de que as experiências importariam em transgressão da liberdade oceânica. Elas implicariam na proibição do acessio de navios a determinadas áreas do alto mar. Haveria também riscos de contaminação do oceano. Menos de dois meses após o ajuizamento da ação (22 de junho de 1973), concedeu a Corte, com base no artigo 41 de seu Estatuto, por 8 votos contra 6, medidas provisórias requeridas pela Austrália e Nova Zelândia, consistentes em que "o governo francês 'deveria evitar testes nucleares causadores de depósito de precipitações radioativas sobre o território daqueles dois Estados" ${ }^{1}$. Entendeu o 
governo de Paris, todavia, realizá-los, e assim o fez a 21 de julho do mesmo ano, declarando, a seguir, reiteradamente, desistir de promovê-los no ano seguinte, em 1974. Reunida a Corte no decurso desse mesmo ano, reconheceu os efeitos jurídicos dessas declarações, que vinculariam o governo francês e, por nove votos contra seis, entendeu, não haver mais controvérsias e decidir ${ }^{2}$

Teve a Corte, porém, ensejo de examinar o mérito de quatro controvérsias, as quais em menor ou maior grau, se reportam à problemática do direito do mar. Trata-se das seguintes, enumeradas em ordem cronológica: 1) sobre o estreito de Corfu: sentença de 9 de abril de 1949; 2) sobre zonas de pesca: sentença de 18 de dezembro de 1951 ; 3) sobre a plataforma continental do mar do Norte: sentença de 20 de fevereiro de 1969; e finalmente, 4) as sobre jurisdição de pesca: sentença de 25 de julho de 1974.

Ao examinar essas disputas, nosso propósito é duplo: o de inferir das respectivas decisões normas de direito internacional, do qual a jurisprudência é uma das fontes (art. 38, n. 2, letra c do Estatuto da C I.J ); e o de aquilatar o grau de receptividade da Corte Internacional de Justiça, pelos membros da comunidade internacional, em face do atual processo de reformulação do direito do mar.

E óbvio que essas controvérsias suscitam sedutoras questões de ordem processual e outras tantas de ordem substan-

1. Nuclear Tests Case (Australia v. France) (Interim Protection Order) (1973) I.C.J.; Nuclear Tests Case (New Zealand v. France) (Interim Protection Order) (1073) (I.C.J.) - Vide igualmente, Goldsworthy, Interim Measures of Protection in the International Court of Justice, A.J.I.L., 1974, pp. 68 e segs.; Lacharrière, Cour Internationale de Justice. Commentaires sur la position Juridique de la France à l'égard de la liceité de ses expériences. AFDr, 1973 , pp. 253 e segs.

2. Nuclear Tests Case (Australia v. France), Judgement of December 20, 1974, I.C.J. Rep. 253; Nuclear Tests Case (New Zealand v. France), Judgement of December 20, 1974, I.C.J. Rep. 457 - Sobre as sentenças: MAC WHINNEY EDWARD, International - Law Making and the Judicial Process: The World Court and The French Nuclear Tests Case, in Syracuse Journal of International Law and Comerce, v. 3, 1975, n. 1, pp. 9/46. 
tiva, que, por carência de tempo, e considerados os objetivos a que nos propusemos, seremos forçados a descurar.

Examinemos a primeira dessas controvérsias que, coincidentemente, foi também a primeira, em sentido cronológico, submetida à jurisdição da Corte.

O litígio ocorreu entre a Grã-Bretanha e a Albânia e disse respeito à passagem de navios de guerra pelo estreito de Corfu, nome de ilha, como se sabe, pertencente à Grécia, mas situada em frente aos limites terrestres desta com a Albânia, de modo que as águas do estreito banham igualmente os dois países, ao norte e ao sul, respectivamente. ${ }^{3}$

Os dados da questão são os seguintes: no dia 15 de maio de 1946, os cruzadores britânicos "Orion" e "Superb", quando passavam pela parte norte de Corfu e se dirigiam para o sul, foram alvo de fogo de bateria albanesa sita na vizinhança de Saranda. O governo do Reino Unido protestara imediatamente. Em troca de notas diplomáticas subseqüentes, cada parte insistia na procedência de sua tese, a Grã-Bretanha em afirmar o princípio de liberdade de navegação pelo estreito e a Albânia, em contestá-lo. Como, porém, nenhum navio fora atingido, a questão circunscrevera-se então a âmbito diplomático e a sustentação de teses doutrinárias. Posteriormente, contudo, houve incidente de maior gravidade, em que navios britânicos foram danificados: o "Saumarez" e o Volage", que, a 22 de outubro de 1946, transitavam pelo estreito, se chocaram com minas submarinas. Houve também mortes e ferimentos em oficiais e marinheiros da equipagem.

Três questões principais a Corte examinou. A primeira delas - suscitada pelo governo albanês - dizia respeito à licitude da passagem dos navios de guerra britânicos pelo estrei-

3. Corfu Channel Case, Judgement of April 9 th, 1949: I C J Reports 1949, p. 4. ChUNG, Il Yung, Legal Problems involved in the Corfu Channel incident. Genève, Droz-Paris, Minard, 1959. Peacetime passage by warships through territorial straits (Columbia Law Review, v. 50, n. 2, 1950, pp. 220-225). 
to, no dia da colisão, apesar da oposição do Estado costeiro. Teria o governo britânico violado, então, a soberania da Albânia? A resposta da Corte foi negativa. Favorável à licitude do trânsito de navios de guerra em estreitos internacionais, a sentença repercutiu, cerca de uma década após, na Convenção de Genebra sobre Mar Territorial e Zona Contígüa (artigo 16, \$ 4..$^{\circ}$. Essa disposição - convém lembrar - se reporta à passagem em estreito internacional. Ela não se refere à passagem por mar territorial. Cabe também notar que, em face do vigente processo de revisão das normas sobre direito do mar, o tema "regime jurídico dos estreitos internacionais" é dos mais complexos na agenda da III Conferência das Nações Unidas sobre Direito do Mar e se encaminha para alcançar sistematização própria, em que ele se distinga quer do regime do mar territorial, quer do regime das águas interiores, quer, enfim, do regime das águas internacionais.

A segunda questão - argüida aliás pela Grã-Bretanha tinha o seguinte enunciado: "Seria a Albânia responsável, de acordio com o direito internacional, pelas explosões que tiveram lugar a 22 de outubro de 1946 nas águas albanesas, por danos e por perdas de vidas humanas que daí resultaram, e existiriam reparações em consequiência a promover?" Foi afirmativa a resposta da Corte. Não porque houvera transgressão da Convenção oitava da Segunda Conferência da Paz de Haia de 1907, como entendera a Grã-Bretanha, pois a Convenção só se aplica em temṕpo de guerra e as relações entre os litigantes se examinavam em função do direito internacional em tempo de paz, mas porque ocorrera a transgressão de princípios gerais de direito bem como considerações elementares de humanidade mais absolutas vigentes em tempo de paz e de guerra, o princípio da liberdade das comunicações marítimas e a obrigação para todo Estado de não deixar utilizar seu território para fins contrários ao direito de outros Estados. E porque a Albânia, devendo estar ciente da existência das minas, não deligenciara para que com elas não colidissem os navios britânicos. 
A 13 de novembro de 1946, alguns dias após o infausto acidente, o governo britânico realizou, não obstante formal oposição albanesa, operação de varredura de minas no estreito. Daí a terceira questão: teria esse governo transgredido a soberania da Albânia e deveria, em consequiência, sujeitar-se a reparações? Alegou a Grã-Bretanha estar, naquelas circunstâncias, autorizada a intervir assim como a colher provas e a agir "para a própria proteção" Não lhe deu razão o Tribunal: "o alegado direito de intervenção" disse ele, "como expressão de uma polícia de força, tal como, no passado, deu origem aos mais sérios abusos, não pode, quaisquer que sejam os defeitos atuais da organização internacional, encontrar lugar no direito internacional". "Entre Estados independentes" - acrescentou a sentença - "o respeito pela soberania territorial é base essencial das relações internacionais"

Menos eriçada de questões, a segunda controvérsia disse respeito, em síntese, à contestação da Grã-Bretanha sobre a juridicidade do decreto norueguês de 12 de julho de 1935, quer quanto às linhas de base, quer quanto ao método empregado para a delimitação das zonas de pesca ${ }^{4}$. Tratava-se de esclarecer, pois, o traçado da linha de base do mar territorial da Noruega, condição preliminar para se apurar a delimitação das zonas de pesca desse país. Segundo o governo britânico, que invocara prática internacional e proposta subsistente na Conferência de Codificação de 1930, deveria a linha de base consistir na linha de baixa-mar, a qual deveria seguir "todas as sinuosidades da costa" Entendeu o governo de Oslo, porém, haver no litoral norueguês condiçốes peculiaríssimas, históricas, geográficas, econômicas, que justificariam se introduzisse exceção ao sistema de linha de baixa-mar. Costume formado entre os países litigantes dava, ademais, lici-

\footnotetext{
4. Fisheries Case. Judgement of December 18th, 1951. I.C.J. Reports 1951, p. 116. AUBI J.M., Les Problèmes de la mer territoriale devant la Cour internationale de Justice, J.D.F., 1953, pp. 24-55. EvenseN, JeNs, The AngloNorwegian Fisheries Case and its legal consequences. AJIL, v. 46 1952, pp. 609-630.
} 
tude ao decreto questionado. Deu a Corte razão à Noruega, tendo a sentença repercutido na Convenção sobre Mar Territorial e Zona Contígüa, cujo artigo $4 .^{\circ}$ dispõe, em seus parágrafos primeiro e quarto, o seguinte: "Nas regiões onde a linha costeira apresenta reentrâncias profundas e saliências, o métrodo das linhas retas, ligando os pontos apropriados pode ser adotado para o traçado da linha de base"; "ter-se-ão em conta, para fixação de determinadas linhas de base, interesses econômicos próprios à região considerada e cuja realidade e importância sejam claramente atestadas por longo uso". Tais preceitos se incorporaram, desde então, pacificamente ao direito internacional e sobre eles não questiona a Conferência das Nações Unidas sobre Direito do Mar, ora em processo de tramitação.

A terceira controvérsia disse respeito à delimitação da plataforma continental do Mar do Norte, o qual, como se sabe, de forma aproximativamente oval, pouco profundo, se encontra quase inteiramente cercado pelas terras do continente europeu e das ilhas britânicas. Prolongamento dessas terras, a plataforma continental aí permanece, com exceção apenas da chamada "fossa norueguesa", a uma distância inferior, em geral, a duzentos metros de profundidade. Rica de petróleo, como o atestam as sondagens que, desde 1963, nela sistematicamente se vêm fazendo, essa plataforma passou a ser objeto de delimitação através de acordos bilaterais entre os Estados da região. Delimitação parcial foi alcançada entre a República Federal da Alemanha e seus vizinhos, ao sul e ao norte, a Holanda e a Dinamarca, respectivamente, nos acordos concluídos a $10^{\circ}$ de dezembro de 1964 e 9 de junho de 1965. Dúvidas, porém, persistiram no prosseguimento do traçado dessa delimitação. Para dirimi-las, deveria a Corte - segundo precisavam os compromissos então assinados - decidir "quais os princípios e regras de direito internacional aplicáveis" A controvérsia foi submetida à Corte Internacional de Justiça, a 2 de fevereiro de 1967, pela República Federal da 
Alemanha, de um lado, e, de outro lado, conjuntamente, pela Dinamarca e Holanda. ${ }^{5}$

Estava em causa a interpretação do parágrafo $20^{\circ}$ do artigo $6^{\circ}$ da Convenção de Genebra sobre a Plataforma Continental. Diz esse parágrafo que se u’a mesma plataforma continental for adjacente aos territórios de dois Estados limítrofes, a delimitação da plataforma é determinada por acordo entre esses Estados e que, na ausência de acordo, e salvo circustâncias especiais, "a delimitação se opera por aplicação do princípio de equidistância dos pontos mais próximos das linhas de base a partir das quais é medida a largura do mar territorial de cada um desses Estados" Não tendo havido acordo, entre, de um lado, a República Federal da Alemanha e, de outro lado, a Dinamarca e a Holanda, a respeito dessa delimitação, entenderam estes dois países que, inexistindo também circunstâncias especiais, deveria prevalecer o princípio da equidistância tal como está prescrito no referido parágrafo. Aduziram ambos os países que, se essa disposição não fosse aplicável às Partes litigantes, a delimitação deveria se operar entre elas "com base nos direitos exclusivos de cada qual sobre a plataforma continental adjacente às suas costas e no princípio segundo o qual a delimitação deve deixar a cada uma das Partes todos os pontos da plataforma continental que estejam mais próximos de suas costas que das costas da outra Parte".

Sustentou a República Federal da Alemanha, em contraposição, que, tendo apenas assinado mas não ratificado a Convenção sobre a Plataforma Continental, não estaria vinculada ao princípio da equidistância, o qual ademais não havia se convertido em norma consuetudinária internacional. Mesmo que estivesse vinculada à Convenção, esse princípio não

5. North Sea Continental Shelf, Judgement, I.C.J. Reports 1969, p. 3 . Vallís, Charles, le Plateau Continental dans le Droit Positif Actuel, Paris, Pedone, 1971. Lavg, Jacques, Le Plateau Continental de la Mer du Nord, Paris, L. G.D.S., 1970 . 
prevaleceria nos termos do citado parágrafo $2 .^{\circ}$ do artigo $60^{\circ}$ - no caso de existirem circunstâncias especiais. Ora, tais circunstâncias especiais subsistiam, aduzia a República Federal da Alemanha, tendo em conta, principalmente, a configuração côncava de suas costas no Mar do Norte. O princípio que deve reger a delimitação - ainda segundo o mesmo país - é aquele segundo o qual "cada Estado ribeirinho tem direito a uma parte justa e equitativa, da plataforma continental disponível, proporcionalmente ao comprimento do seu litoral ou de sua fachada marítima"

A sentença, proferida cerca de dois anos depois de ajuizada a ação, ou seja, a 20 de fevereiro de 1969, decidiu rejeitar quer o princípio da distribuição justa e equitativa, proposto pela República Federal da Alemanha, quer o princípio da equidistância, defendido pela Holanda e Dinamarca. Sustentou a Corte que o fundamento do direito do Estado sobre a sua plataforma continental reside no fato desta ser o prolongamento natural do território terrestre desse Estado, fundamiento este que, aliás, também as Partes litigantes sufragavam, a qual, se bem que, consagradio no artigo 2 da Convenção de Genebra de 1958, era dele inteiramente independente. "A área da plataforma continental" - declara a sentença "constitui prolongamento natural do território do Estado ribeirinho sob o mar. Os direitos deste Estado sobre essa área existem ipso facto e ab initio em virtude da soberania do Estado sobre esse território e, subsistem, como uma extensão dessa soberania, sob a forma do exercício de direitos soberanos para os fins de exploração do leito do mar e de exploração de seus recursos naturais" "Em suma, há aí um direito inerente. Para exercê-lo não é necessário seguir processo jurídico particular nem cumprir atos jurídicos especiais. A sua existência pode ser verificada, como o fizeram numerosos Estados, mas ela não requer nenhum ato constitutivo" Tal direito é, ademais independente de seu exercício efetivo. Para retomar o termo da Convenção de Genebra, ele é exclusivo no sentido de que, "se um Estado ribeirinho preferir não ex- 
plorar sua área de plataforma continental, isto é de sua própria competência e ninguém pode fazê-lo sem seu consentimento expresso" (\$19).

Embora ambos os lados considerassem o princípio do prolongamento do território do Estado como fundamental, acabaram por interpretá-lo de maneiras diferentes e inaceitáveis para o Tribunal (\$ 44) Quanto ao princípio da justa e equitativa distribuição, preconizado pela República Federal da Alemanha, entendeu a Corte estar subjacente a idéia de repartir uma zona ainda não delimitada, idéia essa, no dizer da sentença, "absolutamente estranha e oposta à concepção fundamental do regime da plataforma continental, segundo a qual o ato de delimitação consiste essencialmente em traçar uma linha de demarcação entre zonas já pertencentes a um ou outro dos Estados interessados" "Certo", prossegue a sentença - "a delimitação deve efetivar-se equitativamente, mas ela não poderia ter por objeto atribuir uma parte equitativa nem' mesmo simplesmente uma parte, pois a concepção fundamental na matéria exclui qualquer coisa de indivisível para partilhar" (\$ 20) Quanto ao princípio da equidistância, apoiado pela Dinamarca e Holanda, não havia confundi-lo também com o princípio do prolongamento natural do território do Estado ribeirinho. Nem sempre o ponto mais próximo da costa - em áreas sujeitas à delimitação - significaria ser ele prolongamento natural dessa costa. A fossa norueguesa, de oitenta a cem quilômetros de largura, impedia, por exemplo, fossem as zonas da plataforma continental do mar do Norte, por ela separadas, ser consideradas, no sentido geográfico, adjacentes a esse litoral ou como sendo dele o prolongamento natural $(\$ 45)$

Ao examinar o parágrafo $2 .^{\circ}$ do artigo $6^{\circ}$ da Convenção, interpretando-o histórica e sistematicamente, negou o Tribunal estivesse nele reconhecido, em caráter absoluto, o princípio da equidistância. Este princípio, tal qual está enunciado nessa disposição, fora proposto pela Comissão de Di- 
reito Internacional à Conferência de 1958 com muita hesitação, a título sobretudo experimental e de lege ferenda, e de nenhum modo de lege lata e nem mesmo a título de regra de direito internacional costumeiro em vias de formação (\$ 62) Admite o artigo $6 .^{\circ}$, por sinal, reservas. Tal princípio - conclui o Tribunal - também não se converteu em norma consuetudinária depois de concluída a Convenção (\$81) .

Sublinhou a Corte os resultados diferentes a que o método da equidistância conduz em razão da concavidade ou da convexidade do litoral. Em vantagem do Estado de costas convexas; ou em desvantagem do Estado de costas côncavas, como era precisamente o caso da República Federal da Alemanha. Pode esse método conduzir, em certas hipóteses, "a resultados primacialmente extraordinários, anormais ou incongruentes" (\$ 24), "a uma incontestável iniqüidade" (\$ 89). "A menor deformação do litoral é automaticamlente amplificada pela linha de equidistância com projeções na delimitação da plataforma continental" Por outro lado, nem a República Federal da Alemanha havia ratificado a Convenção sobre Plataforma Continental, nem havia ela reconhecido o princípio de equidistância, nem esse princípio se tornara consuetudinariamente obrigatório.

Em conclusão, a Corte decidiu, por maioria de votos (onze contra seis), não ser obrigatório entre as Partes o método de delimitação baseado na equidistância; e inexistir método único de delimitação obrigatório em todas as circunscias. A delimitação deve operar-se por via de acordo, atribuindo-se a cada Parte, na medida do possível, a totalidade das zonas de plataforma continental que constituam o prolongamento natural de seu território sob o mar e não interfiram no prolongamento natural do território da outra parte.

Tem sido a sentença da Corte considerada bastante fecunda e elucidativa, em relação à problemática das fontes de direito internacional, sobretudo no exame de questões relacio- 
nadas com tratados e costumes internacionais. Quanto ao regime jurídico da plataforma continental, a sentença, além de esclarecer o alcance do critério da equidistância, teve conseqüência relevante ao acolher e ressaltar o conceito da plataforma como o "prolongamento natural", sob o mar, do território do Estado ribeirinho. Tal conceituação acabou de servir de premissa da tese da autonomia do regime da plataforma continental, em face do regime emergente da zona econômica exclusiva, o qual tem sido acolhido, ainda na Terceira Conferência das Nações Unidas sobre Direito do Mar, como área autônoma sujeita a regime jurídico próprio, distinto quer do pertinente ao mar territorial, quer também do relativo ao alto mar. Excluiria o conceito da zona econômica exclusiva o da plataforma continental? Como se sabe, este é um dos poucos pontos discrepantes entre princípios da Conferência de Santo Domingo e os da reunião de Yaoundé; entre países latinoampricanos, de um lado, e países africanos, de outro lado; entre, enfim, países de plataforma continental extensa e os que a têm circunscrita ao âmbito das duzentas milhas marítimas. Diretriz dominante na Conferência das Nações Unidas tende, neste passo, a sufragar os princípios da reunião de Sànto Domingo.

Subsistente a idéia da plataforma continental como "prolongamento natural" do território terrestre, a plataforma não findaria no limite das duzentas milhas marítimas. Uma vez rejeitado o critério de explorabilidade, que equivocadamente a Convenção de 1958 sobre Plataforma Continental oontemplou, o término da plataforma poderá ser determinado em razão de um critério geológico preciso; o do limite exterior da margem continental. Esta é a tendência que, por outro lado, se afigura prevalecente nas reuniões diplomáticas ora em curso.

Examinemos, finalmente, as mais recentes controvérsias concernentes ao direito do mar, as referentes à jurisdição sobre pesca e suscitadas pelo Reino Unido da Grã-Bretanha e pela República Federal da Alemanha contra a Islândia, res- 
pectivamente, a 14 de abril de 1972 e a 26 de maio de 1972 . Julgadas pela Corte na mesma data, ou seja, a 25 de julho do ano passado (há pouco mais de ano e meio), essas controvérsias se relacionam com o gradual aumento de zonas de pesca promovido pela Islândia em torno de seu território insuJar, aumento esse relacionado com o decreto de 30 de junho de 1958, que elevou para doze milhas a zona em que as embarcações islandesas passariam a nela exercer com exclusividade os seus direitos de pesca. Foi esse decreto promulgado, como se verifica, após o malogro da primeira conferência das $\mathrm{Na}$ ções Unidas sobre Direito do Mar em delimitar a largura do mar territorial e das zonas de pesca, malogro esse que, como se sabe, atingiu igualmente a segunda Conferência, realizada, também em Genebra, dois anos mais tarde.

Após período de crise, decorrente da execução desse decreto, houve acordo entre os interessados. Mediante troca de notas, de 11 de março de 1961 e de 19 de julho do mesmo ano, a Grã-Bretanha e a República Federal da Alemanha, respectivamente, acabaram por reconhecer a ampliação da zona de pesca islandesa.

Transcorridos dez anos, ou seja, a 14 de julho de 1971, o governo da Islândia anunciava o término dos acordos de pesca então subsistentes com a Grã-Bretanha e a Alemanha Ocidental assim como a ampliação dos limites de pesca para cincoenta milhas. A majoração se iniciaria um ano mais tarde, a 14 de julho de 1972. Após o anúncio da nova majoração, para cincoenta milhas, e antes que ela se tornasse efetiva, a Grã-Bretanha, de início, e a seguir, a República Federal da Alemanha ajuizaram ação contra a Islândia. Correram os processos autonomamente, conquanto na essência o fundamento dos pedidos fosse o mesmo.

A inicial e o memorial dos autores pediam que a Corte julgasse e declarasse: a) não encontrar fundamento no direito internacional a pretensão da Islândia de estender sua 
jurisdição através do estabelecimento de zonas exclusivas de jurisdição de pesca até 50 milhas de distância das linhas de base; ḅ) não ser lícito à Islândia reservar-se jurisdição exclusiva de pesca além dos limites acordados na Troca de Notas de 1961, ou impedir a presença de baroos de pesca além desses limites ou impor-lhe restrições; c) dever a Islândia pagar indenização por atos ilícitos cometidos além desses limites ${ }^{6}$.

A sentença sobre o mérito da controvérsia, é de 25 de julho de 1974. Após as Conferências de Genebra de 1958 e 1960 , lembra a Corte, dois conceitos se cristalizaram como direito consuetudinário: o de zona de pesca, área em que, até o limite presumível de doze milhas, o Estado pode reivindicar jurisdição exclusiva para exploração de recursos biológicos, independentemente de seu mar territorial; e o de direitos preferenciais de pesca em águas adjacentes em favor do Estado costeiro em uma situação de dependência especial sobre sua pesca litorânea, preferência essa oponível aos demais Estados interessados na exploração das mesmas águas, a ser implementada por via de acordo entre todos esses Estados ou, não sendo esse acordo possível, através dos meios de solução pacífica de controvérsias previstas no artigo 33 da Carta das Nações Unidas. A Corte declara estar ciente de que um certo número de Estados costeiros se tem manifestado em favor do alargamento de sua jurisdição costeira. Está ciente ademais da convocação da terceira Conferência das Nações Unidas sobre Direito doı Mar. Todavia, acrescenta, "como um Tribunal de direito, não pode proferir julgamento sub specie legis ferendae, ou antecipar o direito antes que o legislador o tenha elaborado".

6. Fisheries Jurisdiction (United Kingdom v. Iceland), Merits, Judgement, I.C.J. Reports 1974, p. 3. Fisheries Jurisdiction (Federal Republic of Germany v. Iceland), Merits, Judgement, I.C.J. Reports 1974, p. 175. CHuRCHILL, R.R. The Fisheries Jurisaiction Cases: The Contribution of the International Court of Justice to the debate on Coastal States' Fisheries Rights, ICLQ, 1975, pp.82105. 
Não se referiu a sentença, em sua conclusão, ao primeiro pedido dos Estados autores, a saber, de que a Corte declarasse que a pretensão da Islândia de estender uma zona de jurisdição de pesca até 50 milhas não encontrava amparo no direito internacional. Acolheu, porém, os demais pedidos. Por dez votos contra quatro, entendeu não prevalecer contra a Grã-Bretanha o Regulamento de 14 de julho de 1971 que estendera até 50 milhas os direitos exclusivos de pesca da Islândia; julgou não estar o: governo islandês autorizado, por atos unilaterais, a excluir barcos pesqueiros britânicos ou alemães de áreas entre 12 milhas, tal como se estipulara no acordo de 11 de março de 196.1, e 50 milhas como passou a prescrever aquele Regulamento. Também por dez votos contra quatro, o Tribunal prescreveu estarem os governos litigantes na obrigação recíproca de encetarem negociaçães de boa fé para solução equitativa de suas disputas, recomendando-lhes, para tanto, uma série de prescrições a serem atendidas por essas negociações.

Em suma, a decisão do Tribunal, contrária à Islândia, partiu da premissa de que a majoração da zona de pesca para cincoenta milhas infringia acordos bilaterais em que se restringia essa zona a doze milhas marítimas. Teria essa majoração importado, igualmente, em infringência do direito internacional comum ou geral, de princípios gerais de direito, de normas consuetudinárias universais? A Corte nada esclareceu a respeito. Ela se cingiu, em grande parte, a examinar a licitude de ato unilateral de um governo em face de acordos bilaterais subscritos por esse governo dez anos antes.

$E$, nesse sentido, restrita, se não nula, a contribuição da sentença ao desenvolvimento do direito internacional. A Corte dera, precedentemente, contribuições mais sensíveis e mesmo marcantes, usando, por vezes, de equidade não apenas "secundum" mas também "praeter legem": a regra da licitude da passagem de navios de guerra por estreitos internacionais, o reconhecimento de princípios gerais de direito apli- 
cáveis ao direito do mar, a condenação de atos de força sob a invocação do direito de proteção, como se infere do litígio sobre o canal de Corfu; a admissibilidade do traçado de linha reta em circunstâncias especiais, segundo se preceituou na sentença sobre delimitação do mar territorial norueguês; o conceito de plataforma continental como: prolongamento natural do território terrestre do Estado ribeirinho, segundo reza a sentença sobre a delimitação da plataforma continental do mar do Norte. Sem embargo, a controvérsia sobre a ampliação da zona de pesca islandesa poderia ser esclarecida sobre outros aspectos, inclusive sobre a natureza do direito do mar e legitimidade da Corte Internacional de Justiça.

Ponto de relevância consiste no fato de haver a Corte silenciado sobre o primeiro pedido dos autores, o de que os atos da Islândia constituiam transgressão do direito internacional. Não haveria necessidade de o dizer, embora fosse conveniente o disssesse, eis a linha de argumentação de sir HuMPhrey Waldock e de Gros, em seus votos vencidos. Para o juiz Ignácio PinTo, ao não dar resposta inequívoca ao principal pedido, a Corte descumpriu ato de justiça que se lhe requerera. Cinco juízes assinalaram, porém, em voto separado, subscrito conjuntamente, o fato que lhes tornou possível subscrever a sentença: enquanto ela declarava ser o alargamento da jurisdição de pesca pela Islândia contrário aos direitos históricos dos Estados autores, a mesma sentença não estatuía, porém, como pediram esses Estados, que tal alargamento era contrário ao direito internacional e inválido erga omnes. Não há, no presente, dizem esses juízes, (Forster, Bengzon, Jiménez de Aréchaga, Nagendrä Singh e Rudä), regra geral de direito consuetudinário estabelecendo para $\mathbf{o}$ Estado Costeiro o limite de pesca máximo de doze milhas. Iniciada na América Latina, a tendência para o alargamento desse limite - aduzem eles - acabou se estendendo a países do continente africano e asiático, provocando reformulação tal do direito do mar que motivou a convenção da Terceira Conferência sobre o Direito do Mar. $\mathrm{O}$ aparecimento de 
novos conceitos, como o de zona econômica exclusiva, largamente aceitos, favoreceram, outrossim, no dizer dos mesmos juízes, a incerteza das regras sobre direito do mar e impossibilitaram à Corte acolher integralmente o pedido dos autores.

Como se notou, enquanto as sentenças eram proferidas, realizava-se a segunda sessão da Terceira Conferência das Nações Unidas sobre Direito do Mar, onde elas acabaram repercutindo, como que a dar a penosa impressão de deliberada advertência ou intervenção. De um lado, em Haia, cuidava-se, em princípio, de aplicar o direito vigente, de decidir de lege lata; de outro lado, em Caracas, cuidava-se de codificar e de desenvolver o direito internacional do mar, em franco processo tanto então como hoje, de transformaçãa, processo esse no qual se havia de ter em conta quer o direito constituído, quer o direito constituendo. Expressa numa perspectiva assaz conservadora, de que apenas poucos Estados, desenvolvidos, eram solidários em Caracas, a sentença sufragava categorias como de zona de pesca e direitos preferenciais - que a Conferência acabaria por entender obsoletas ou inaceitáveis.

O ritmo de transformação do direito do mar é, na verdade, poderoso e surpreendente, e nem sempre é fácil de marcar com nitidez absoluta as fronteiras entre as normas de lege lata e as normas de lege ferenda. Foi o que, aliás, de certo modo, se deu conta a Corte ao examinar a sua própria tarefa em face de um direito tão dinâmico como as próprias ondas do mar. Em face da transformação constante desse direito, não deveria , ela, é claro, abdicar de suas funções. "A Corte" disse a sentença $(\$ 40)$ - "é de parecer não haver incompatibilidade com suas funções judiciais ao fazer pronunciamento sobre direitos e deveres das Partes em face do direito internacional vigente, o qual poderia ser claramente capaz de ter um progressivo avanço" "A possibilidade de um direito cambiante é sempre presente: mas isso não exime a Corte de seu dever de decidir na base do direito vigente ao tempo em que a decisão for tomada" (ibidem) . 
A sentença não fora proferida, contudo, no entender de juízes dissidentes, em função do direito constituído. A Corte ter-se-ia deixado levar pelas tentações do direito constituendo. Conforme a crítica do juiz Ignácro-Pinto, "a maioria da Corte parece ter adotado posição com a intenção de indicar o caminho para os participantes da Conferência sobre o Direito do Mar". Coube ao juiz Dillard focalizar acuradamente, com remissões até a ARISTóteles, distinção entre justiça corretiva e justiça distributiva. Enquanto a justiça corretiva, adequada às funções e natureza da Corte, trataria de restabelecer o direito violado, a justiça distributiva cuidaria de estabelecer um sistema de repartição equitativa de recursos. $\mathrm{Da}$ justiça distributiva estaria a cuidar a Conferência das Nações Unidas sobre Direito do Mar. Da justiça corretiva haveria de cuidar, primacialmente o tribunal de Haia. A dificuldade dos pleitos contra a Islândia estava, contudo, em que neles se envolviam não apenas elementos de justiça corretiva mas também de justiça distributiva. Essa foi a razão pela qual, explica Dillarde, a parte conclusiva da sentença acabaria por remeter' as partes a uma negoc:ação bilateral, de um gênero por sinal semelhante às negociações que, embora coletiva e universalmente, estavam em curso, concomitantemente, sob o patrocínio das Nações Unidas.

Em relação à mesma temática, assinalaram, em seu voto separado conjunto, os cinco juízes acima citados, não poder a Corte eximir-se de conhecer de diversos pronunciamentos de Estados, feitos em sentido claramente reformista, sob a alegação de que teriam sido formulados num contexto de lege ferenda. Não seria possível repeli-los, considerando-os como despidas de significação jurídica ( $\$ 12)$

A questão a nosso ver talvez pudesse ser devidamente equacionada num sentido de perquirição de nova fonte do direito internacional. Depois de haver quase a totalidade dos Estados se manifestado nas sessões plenárias iniciais da reunião de Caracas, em favor de novos conceitos como o de mar 
patrimonial ou de zona econômica exclusiva, que absorve e transcende, e por isso mesmo os exclui, os conceitos de direitos preferenciais e de zona de pesca, depois desse pronunciamento fortemente majoritário dos Estados participantes da reunião, é lícito perguntar se o direito internacional positivo estaria no costume internacional, objeto de veneração especial em Haia, ou nessas manifestações oficiais e concordantes de governo que não são a rigor nem costume nem tratado internacional. Como lembrava Virally, há mais de uma década, as contribuições respectivas do costume e dos tratados não terão logo mais nada a ver com o que eles representavam outrora. "Durante muito tempo, o direito internacional geral foi exclusivamente de origem costumeira e era inconcebível fosse de outra maneira: os tratados não podiam regulamentar senão as relações particulares entre dois ou alguns. Estados. A convocação das conferências internacionais, ao reunirem a quase totalidade dos Estados do mundo, está em vias de mudar essa situação. Divisa-se o momento em que as regras escritas constituirão o direito internacional geral" "

Cremos que este momento chegou, pelo menos no tocante ao direito do mar, pois as sessões pertinentes da III Conferência das Nações Unidas abrangem maior número de membros componentes do que a própria Organização que as promove e patrocina. Não apenas todos os Estados, praticamente, delas participam, banhados ou não por águas marítimas, senão também - com direito de palavra embora não de voto os chamados "movimentos de libertação nacional" que aspiram converter-se, proximamente, em Estados. Após o início da Conferência, ocorrido há dois anos e meio, alguns desses movimentos já atingiram o seu desideratum. E o caso de Moçambique e o de Angola.

Prevalece na Conferência a tendência de constituirem-se dois novos tribunais, órgãos de solução judiciária com com:

7. Le Droit International en Question, Archives de Phllosophle du Droit, 1963, n. 8, p. 153. 
petência para dirimir controvérsias sobre direito do mar. Um deles se denomina precisamente "Tribunal sobre Direito do Mar". Integrá-lo-ão, em princípio, segundo o atual Texto Informal Único de Negociações, nove juízes, eleitos para um período de nove anos, podendo ser reeleitos. Com o mesmo número de juízes, providos, contudo, de mandato de apenas cinco anos, com possibilidade também de renovação, está previsto, igualmente, o Tribunal da Autoridade dos Fundos Oceânicos Internacionais. Essa Autoridade, cuja sede foi proposta para a Jamaica, é a organização através da qual os Estados administrarão o leito oceânico, seu sub-solo e respectivos recursos, situados além dos limites da jurisdição nacional, área e recursos esses qualificados, de forma lapidar, como "herança comum da humanidade". O Tribunal é um dos cinco órgãos da Autoridade. Os demais são a Assembléia, o Conselho, o Secretariado e, finalmente, a Empresa, cujo escopo é o de prospectar e explorar os recursos dos fundos oceânicos, devendo, para tanto, ostentar personalidade jurídica internacional e capacidade para a consecução de seus objetivos.

Quanto à escolha dos juízes, o processo diferirá sensivelmente, segundo se prevê, do estipulado para a Corte Internacional de Justiça. Os juízes do Tribunal do Direito do Mar serão eleitos pelas Partes Contratantes em votação secreta, tendo por base uma lista em que competirá a cada Parte indicar no máximo duas pessoas. Os juízes do Tribunal da Autoridade da Área (ou seja dos Fundos Oceânicos) serão escolhidos pela Assembléia, mediante recomendação do Conselho. Enquanto a Assembléia é integrada por todos os Estados partes da Convenção, o Conselho será composto por 36 membros, em que os Estados desenvolvidos e poderosos não terão o caráter de permanência ou de predomínio como o possuem no Conselho de Segurança das Nações Unidas, cuja vontade, como se sabe, é decisiva na escolha das pessoas componentes da Corte Internacional de Justiça, e, a prova está em que juizes deles originários estão constantemente a integrá-la (exceção apenas dos de nacionalidade chinesa). 
A intenção de constituir novos órgãos de solução judiciária não decorre do desejo de aliviar eventual sobrecarga de tarefas da Corte Internacional de Justiça, mas reflete atmosfera de ceticismo e desencanto que a envolve. Certo, invoca-se, como argumento, a conveniência de se instituírem órgãos destinados a aplicarem aos litígios normas de um ramo do direito internacional e a vantagem de haver juízes especializados. A alegação, contudo, não procederia. Os Estatutos da Corte Internacional de Justiça permitem a instituição de câmaras para conhecerem de determinadas categorias de matérias (artigo $26, \S 1 .^{\circ}$ ). Ao contrário de sobrecarga, tem a Corte padecido de carência de atividade judicante, o que demonstra a natureza da crise que a assola. Ao longo de toda a sua existência, no total de 17 anos, a Corte Permanente de Justiça Internacional, órgão de solução judiciária da Sociedade das Nações, havia examinado 69 litígios; $51 \mathrm{em} /$ matéria contenciosa e 28 em matéria consultiva ${ }^{8}$; em igual número de anos, a atual Corte proferiu apenas a metade dessas decisões. Menos de 50 Estados - ou seja, menos de um terço dos Membros das Nações Unidas - aceitam a jurisdição compulsória da Corte Internacional de Justiça e poucos o fazem sem reservas.

A inércia do Tribunal, por um lado, é verdade, resulta do reconhecimento de que grande parte dos litígios internacionais mais bem se adapta a processos políticos que jurídicos. Mas reside, outrossim, em fatores intrínsecos, na posição reiterada em negar sua própria competência em diversos pleitos a ele submetidos, abdicando como que voluntariamente de uma função positiva e marcante, que lhe fora especialmente destinada. Não se ignoram também as tergiversações, a que a Corte tem estado sujeita, argüição essa sustentada, em diversos núcleos governamentais e doutrinários, em razão principalmente de seu comportamento em face do pleito sobre 411.

8. LUIz Garcia ARtas, el Primer Caso del Canal de Corfu, Redi, 1948, p. 
o Sudoeste Africano. Ainda agora, em relação à controvérsia da Grã-Bretanha e República Federal da Alemanha contra a Islândia, a Corte se eximiu, como vimos, de responder ao primeiro pedido dos autores, o de que a Islândia teria transgredido normas de direito internacional geral ou costumeiro. A Corte não respondeu nem sim nem não. Ela tão somente silenciou. Explica-se, desse modo, haja a Islândia - que, aliás, nem sequer se defendeu perante a Corte, à qual negou sempre competência - persistido em suas teses e, mais do que isso, as ampliado. Enquanto ela majora sua jurisdição não apenas de doze para cincoenta milhas mas de cincoenta para duzentas milhas marítimas, o que ocorre desde 15 de outubro do ano passado, e enquanto essa ampliação não se refere apenas a zonas de pesca mas ao próprio mar territorial, acirra-se o conflito a que pitorescamente se denomina de "guerra do bacalhau" O pitoresco apenas suaviza mas não elide a gravidade do conflito do qual emergem sérias conseqüências políticas, econômicas e sociais.

Se indagarmos das causas do ceticismo que cerca o Tribunal, convém atentar para o fato de que, nas controvérsias sobre direito do mar, o círculo dos litigantes se encontra circunscrito a Estados europeus. A Corte das Nações Unidas parece reduzir-se a um tribunal regional. Não será difícil identificar entre essas causas a forma de escolha dos juízes, a qual atende a critério, não de igualdade, como o defendido por Ruy Barbosa na Conferência da Paz de 1907, mas àquele justificado em contraposição por Albert de LA Pradelle, em curso professado há mais de quatro décadas, precisamente sobre direito do mar, em que o insígne jurista assim se expressava: "Se toda nação deve ter um juiz no tribunal, quando para ela se trata de ser julgada, apenas as grandes potências, órgão diretor da Sociedade dos Estados, merecem ter nele um juiz quando se trata não de seu próprio litígio, mas dos litígios dos outros" Ocorre, porém, que, no tocante a esse direito - eis a ponderação com que desejamos encerrar esta aula - a função das grandes potências não se circunscreve a 
de julgar, como órgãos eventualmente neutros e imparciais, mas abrange também o de participar do processo legiferante das normas internacionais e em função de critérios e de interesses próprios que não coincidem necessariamente com os dos demais membros da comunidade internacional. Significam os oceanos veículo de comunicação, reserva de riquezas, fonte de energia, centro de poder. A alimentação do homem neles encontra sustentáculo. Estão à espera de serem escolhidos os nódulos de minerais depositados nos leitos oceânicos, enquanto no sub-solo das plataformas continentais jazem os cobiçados recursos petrolíferos. A ciência jurídica é convocada para dar sua contribuição. É indispensável dá-la. "O mar", como lembrara a propósito Ruy BARBosa, em outra oportunidade, "é o grande avisador". "Pô-lo Deus a bramir junto ao nosso sono, para nos pregar que não durmamos". Importa permaneçamos despertos e vigilantes. 